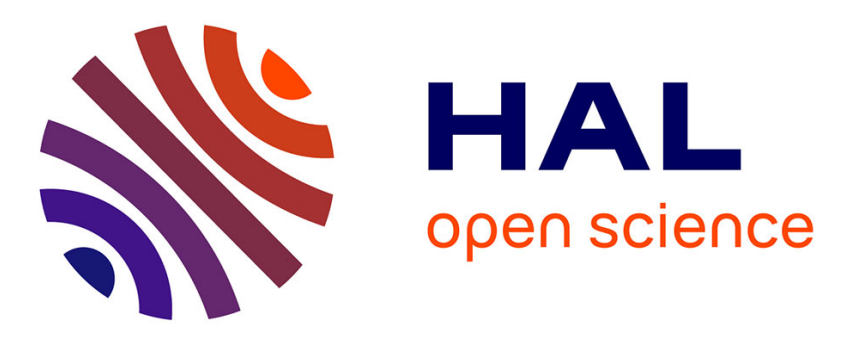

\title{
Electroswitchable red-NIR luminescence of ionic clustomesogen containing nematic liquid crystalline devices.
}

Marianne Prévôt, Maria Amela-Cortes, Kaylan Suman Manna, Stéphane Cordier, Thierry Roisnel, Hervé Folliot, Laurent Dupont, Yann Molard

\section{To cite this version:}

Marianne Prévôt, Maria Amela-Cortes, Kaylan Suman Manna, Stéphane Cordier, Thierry Roisnel, et al.. Electroswitchable red-NIR luminescence of ionic clustomesogen containing nematic liquid crystalline devices.. Journal of Materials Chemistry C, 2015, 3 (15310), pp.5152-5161. 10.1039/C5TC00632E . hal-01153411

HAL Id: hal-01153411

https://hal-univ-rennes1.archives-ouvertes.fr/hal-01153411

Submitted on 19 Jun 2015

HAL is a multi-disciplinary open access archive for the deposit and dissemination of scientific research documents, whether they are published or not. The documents may come from teaching and research institutions in France or abroad, or from public or private research centers.
L'archive ouverte pluridisciplinaire HAL, est destinée au dépôt et à la diffusion de documents scientifiques de niveau recherche, publiés ou non, émanant des établissements d'enseignement et de recherche français ou étrangers, des laboratoires publics ou privés. 


\title{
Electroswitchable Red-NIR luminescence of ionic clustomesogen containing nematic liquid crystalline device
}

\author{
M. Prévôt, ${ }^{a, b}$ M. Amela-Cortes, ${ }^{a}$ S. K. Manna, ${ }^{c}$ S. Cordier, ${ }^{a}$ T. Roisnel,,${ }^{a}$ H. Folliot, ${ }^{b}$ L. Dupont ${ }^{c}$ and Y. \\ Molard $^{a, *}$
}

We describe in this work several poly ionic hybrid molecular compounds combining, by electrostatic interactions, liquid crystalline ammonium cations and tailor made molybdenum hexanuclear dianionic cluster units. All hybrids show nematic liquid crystalline behaviour below $100^{\circ} \mathrm{C}$, no matter the nature of the metallic cluster apical and inner ligands. They also keep the shiny deep red photoluminescence properties of their parent cluster in the nematic phase. This nematic phase re mains however quite viscous for all compounds and mixing them with commercially available nematic LC seems mandatory to integrate them in electroswitchable devices. This particularity, conducted us to insert the best candidate in terms of homogeneity and stability of the clustomesogen/commercial LC mixture in a LC cell and study the behaviour toward application of an electric stimulus. We show that application of a $30 \mathrm{~V}$ AC voltage allows observing a reversible modulation of the photoluminescence signal by about 52\%. This work presents the first deep red photoluminescent transition metal clusters containing device directed towards optoelectronic applications.

\section{Introduction}

Luminescent liquid crystals are of peculiar interest in the fields of optoelectronic applications. Achieving polarized emission or scattering based electro-optical switching via these compounds offers promising perspectives to control the photoluminescence of materials in luminescent devices. ${ }^{1}$ However, developing smart materials with stable and switchable photoluminescence still remains challenging. Beside the "all-organic" strategy that suffers from photobleaching, other possibilities have to be and have been explored to integrate, in a first attempt, luminescence properties in liquid crystal (LC). Of peculiar interest is the use of luminescent metallic centres. In that way, according to K. Binnemans, ${ }^{2,3}$ metal containing liquid crystals (metallomesogens) ${ }^{4-6}$ made of luminescent metallic ions appear as the most promising, in particular when the emissive excited states are metal centred like when trivalent lanthanide ions such as $\mathrm{Eu}(\mathrm{III}), \mathrm{Tb}(\mathrm{III}), \mathrm{Sm}(\mathrm{III})$ are used. ${ }^{2,3}$ However, even if they are interesting owing to their sharp emission band, their absorption coefficient are very low and the use of strongly absorbing organic ligands that act as "antenna" for light absorption" is mandatory to obtain satisfying emission. Another approach would be to insert luminescent inorganic nanoparticles among which quantum dots such as $\mathrm{CdSe} / \mathrm{ZnS}^{8,9}$ or the more environmentally friendly ZnO nanoparticles ${ }^{10-}$ ${ }^{14}$ appear as promising candidates. Some studies have shown that mixture of those QD with commercially available LC was possible, however phase segregation phenomena occur even at low concentration when inorganic moieties are not appropriately coated. ${ }^{15}$ We recently described a new approach to design luminescent liquid crystal by introducing a new family of hybrid compounds named "Clustomesogen". ${ }^{16-21}$ The term Clustomesogen refers to liquid crystalline hybrid materials containing transition metal atom clusters. These materials combine the tremendous self-assembling abilities in the solid state or in solution of liquid crystals (LC) with the metallic clusters intrinsic properties related to the number of metallic electrons available for metal-metal bonds (VEC) such as luminescence, redox states and/or magnetism. ${ }^{22,23}$

The term "metal atom cluster" was introduced by F.A. Cotton in 1964 to design aggregates of metal atoms linked together by metal-metal bonds. ${ }^{24}$ Nano-sized octahedral metallic clusters found in $\left[\mathrm{M}_{6} \mathrm{X}_{8} \mathrm{X}_{6}\right]^{\mathrm{n}}{ }^{\mathrm{n}}$ anionic units (M=Mo, $\mathrm{W}$, or Re;

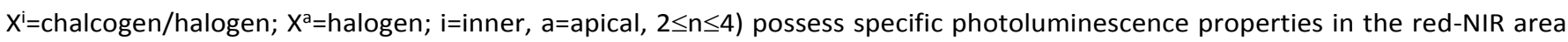
with quantum yields up to 0.80 and long excited state lifetimes in the range of several tenth of microseconds. ${ }^{25-28}$ Their alkali or divalent cation salts are obtained by high temperature solid state synthesis as powders or single crystals and show a ceramic-like behaviour that strongly limits their potential in the design of functional devices. Thus, many investigations have been directed toward the solubilisation, in aqueous or organic solution, of cluster-based inorganic solids, to design new molecular building block toys suitable for the organometallic, coordination and hybrid materials chemistries playgrounds. ${ }^{29-37} \mathrm{~A}$ fair solubility in organic media can be achieved after a cationic metathesis reaction between $A_{n}\left[M_{6} X_{8}^{i} X_{6}{ }_{6}\right]$ inorganic salts $\left(A=\right.$ alkali or divalent cation) ${ }^{24}$, 30 and organic cations. ${ }^{30,38}$ This solubilisation allows their direct integration in hybrid materials ${ }^{32-34}$ and/or their functionalization with one or several organic ligands orthogonally arranged around the cluster core. ${ }^{30,31,39-45}$ We recently described several strategies to design metal cluster containing liquid crystalline material (clustomesogen): i) a covalent approach that consists in the covalent grafting of six promesogenic organic ligands in the apical positions of a Mo ${ }_{6}$ cluster core. ${ }^{16}$ This first supramolecular material self-organizes in layers (smectic phase) on a large temperature range $\left(22-103^{\circ} \mathrm{C}\right)$. ii) An electrostatic technique based on the ionic self-assembly ${ }^{46-48}$ (ISA) strategy that takes advantage of the charge and redox properties of $\left[\mathrm{M}_{6} \mathrm{Q}_{8} \mathrm{CN}_{6}\right]^{\mathrm{n}-}(\mathrm{M}=\mathrm{Mo}, \mathrm{Re}$; $\mathrm{Q}$ $=\mathrm{Br}$, Se; $\mathrm{n}=2,3,4)$ clusters units. In these cases, we could show that the hybrid materials self-assembling abilities were conditioned 
mostly by the number and repartition of liquid crystallinec promoters around the inorganic ionic core. Despite their mesomorphic character, clustomesogen exhibiting a nematic LC phase are very scarce and more particularly if they are obtained by the ISA technique. Hybrid materials that exhibit a nematic phase are very interesting from a technological point of view. As the nematic phase is the most fluid of the LC phases, it allows a faster response to an external stimulus such as the application of a magnetic or electric field. In the present work, we report a full family of halogenated clusters containing clustomesogens obtained by ISA and showing only a nematic behaviour. We demonstrate for the first time that this family of hybrid materials can be used in the design of electro-controlled photoluminescent devices by taking advantage of the stable red NIR photoluminescence of the isotropic metallic nanoclusters.

\section{Results and discussion}

\section{Synthesis}

Mesomorphic hybrid compounds are made of $\left[\mathrm{Mo}_{6} \mathrm{X}_{8} \mathrm{X}_{6}{ }_{6}\right]^{2-}$ cluster units associated with trialkylmethylammonium counter-cations bearing cyanobiphenyloxy terminated alkyl chains (Scheme 1). Tailor made $\left[\mathrm{Mo}_{6} \mathrm{X}_{8} \mathrm{X}_{6}{ }_{6}{ }^{2-}\right.$ cluster units were prepared to study the influence of halogen ligands on the interactions between the cluster units and the organic cations on the one hand and the influence of the cluster size on the LC properties on the other hand. $\mathrm{Cs}_{2} \mathrm{Mo}_{6} \mathrm{X}_{8} \mathrm{X}^{\mathrm{a}}{ }_{6}$ with $\mathrm{X}^{\mathrm{i}}=\mathrm{X}^{\mathrm{a}}=\mathrm{Cl}$, $\mathrm{Br}$, I were prepared by solid state synthesis ${ }^{49-54}$ while $\mathrm{Cs}_{2} \mathrm{Mo}_{6} \mathrm{X}_{8}{ }_{8} \mathrm{X}_{6}{ }_{6}$ with $\mathrm{X}^{\mathrm{i}}=\mathrm{Br}$ and $\mathrm{X}^{\mathrm{a}}=\mathrm{Cl}$, I were prepared from $\mathrm{Cs}_{2} \mathrm{Mo}_{6} \mathrm{Br}_{8}^{\mathrm{i}} \mathrm{Br}^{\mathrm{a}}{ }_{6}$ by apical ligand exchange reactions in solution. The trisubstituted ammonium cation was chosen for several reasons: $i$ ) the cyanobiphenyl (CB) unit is a very wellknown mesomorphic promoter, ii) a similar cation that was previously used to design langmuir blodget films showed homeotropic LC properties, ${ }^{55} \mathrm{iii}$ ) by comparing the cross-section area of molybdenum clusters with the transverse cross section area of one CB unit (20-24 $\left.\AA^{2}\right)$, it appears that between 5 and $7 \mathrm{CB}$ units are mandatory to counterpart the clusters cross section area. This assumption is well illustrated by the geometric data gathered in Table 1 for $\left[\mathrm{Mo}_{6} \mathrm{X}_{8} \mathrm{X}^{\mathrm{a}}{ }_{6}\right]^{2-}$ with $\mathrm{X}^{\mathrm{i}}=\mathrm{Cl}, \mathrm{Br}, \mathrm{I}$ and $\mathrm{X}^{\mathrm{a}}=\mathrm{Cl}, \mathrm{Br}, \mathrm{I} .{ }^{52,53}$

It turns out that, depending on the inner and apical ligands, the cluster unit cross section area varies significantly from $116 \AA^{2}$ to $151 \AA^{2}$ for $X^{i}=X^{a}=C l$ and $X^{i}=X^{a}=$ l respectively; iv) hybrid materials made of $\left[\mathrm{Mo}_{6} \mathrm{Cl}_{8} \mathrm{Cl}_{6}{ }_{6}\right]^{2-}$ (smallest cluster unit) whose charge is counterbalanced by a bisubstituted ammonium organic cation as the one used in one of our previous studies ${ }^{18}$ (Katb, scheme 1 ) does not show any liquid crystalline properties but gave instead single crystals. The latter were suitable for single crystal $\mathrm{X}$-ray

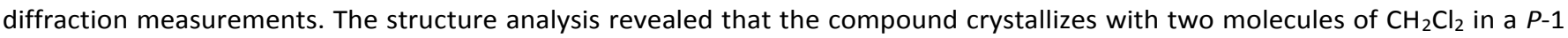
triclinic crystal system $\left(V=2775 \AA^{3}, Z=1, d=1.596 \mathrm{~g} . \mathrm{cm}^{-3}\right)$. Within the crystal, the hybrid self-arranges in a succession of inorganic and organic layers with an interlayer spacing of $21.9 \AA$. In this case, CB units are fully interdigitated and tilted as compared to the normal of the inorganic planes by an angle of around $45^{\circ}$ (Figure 1, details about the structure analysis are provided in ESI. Our attempts to crystallize other cluster units with this cation did not lead to the formation of crystals suitable for X-ray diffraction measurements, neither to mesomorphic material). 


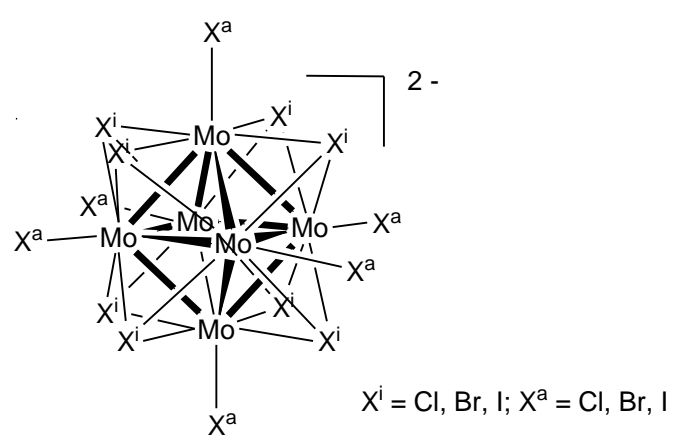

$\left[\mathrm{Mo}_{6} \mathrm{X}_{8}^{\mathrm{i}} \mathrm{X}_{6}^{\mathrm{a}}\right]^{2-}$

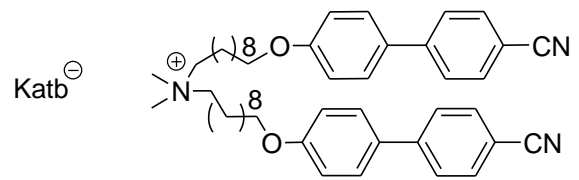

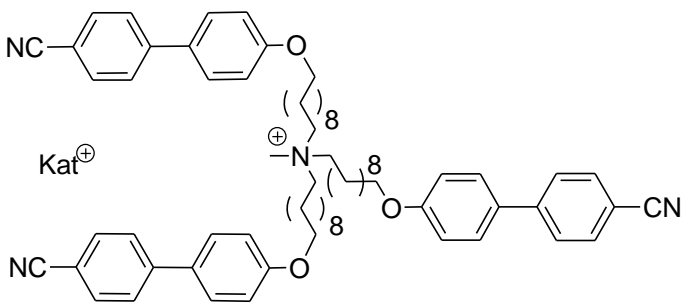

Scheme 1. General representation of octahedral Molybdenum cluster units and of the organic promesomorphic cations used in this study.

Table 1. Geometric parameters of studied $\mathrm{Mo}_{6}$ clusters units (c.u.).

\begin{tabular}{|c|c|c|c|c|c|}
\hline & $\begin{array}{c}\mathrm{d}_{\mathrm{Mo-Mo}} \\
/ \AA\end{array}$ & $\begin{array}{c}\mathrm{d}\left(\mathrm{Mo}^{\circ} \mathrm{X}^{\mathrm{a}}\right) \\
/ \AA\end{array}$ & $\begin{array}{l}\mathrm{R}_{\text {c.u. }} \\
/ \AA\end{array}$ & $\begin{array}{l}\mathrm{A}_{\text {c.u. }} \\
/ \AA^{2} \\
\end{array}$ & $\mathrm{Nb}_{\mathrm{CB}}$ \\
\hline$\left[\mathrm{Mo}_{6} \mathrm{Cl}_{8}^{\mathrm{i}} \mathrm{Cl}_{6}^{\mathrm{a}}\right]^{2-}$ & 2.612 & 2.420 & 6.08 & 116 & $4.8-5.8$ \\
\hline$\left[\mathrm{Mo}_{6} \mathrm{Br}_{8}{ }_{8} \mathrm{Cl}_{6}^{\mathrm{a}}\right]^{2-}$ & $2.636^{\mathrm{a})}$ & $2.451^{\text {a) }}$ & 6.12 & 118 & $4.9-5.9$ \\
\hline$\left[\mathrm{Mo}_{6} \mathrm{Br}_{8}^{\mathrm{i}} \mathrm{Br}_{6}^{\mathrm{a}}\right]^{2-}$ & $2.640^{\text {a) }}$ & $2.491^{\text {a) }}$ & 6.32 & 125 & $5.2-6.3$ \\
\hline$\left[\mathrm{Mo}_{6} \mathrm{Br}^{\mathrm{i}}{ }_{8} \mathrm{I}_{6}^{\mathrm{a}}\right]^{2-}$ & $2.644^{\text {a) }}$ & $2.815^{\text {a) }}$ & 6.88 & 149 & $6.2-7.5$ \\
\hline$\left[\mathrm{Mo}_{6} \mathrm{I}_{8}{ }_{8} \mathrm{I}_{6}{ }_{6}\right]^{2-}$ & $2.675^{\mathrm{b})}$ & $2.850^{\mathrm{b})}$ & 6.94 & 151 & $6.3-7.6$ \\
\hline
\end{tabular}

${ }^{a)}$ values taken from ${ }^{[16 \mathrm{~d}]}$; b) values taken from ${ }^{[16 \mathrm{e}]} ; \mathrm{R}_{\mathrm{c.u}}$ is calculated as the average distance between opposite apical ligands including their effective ionic radius $\left(\mathrm{R}\left(\mathrm{X}^{-}\right)=1.81(\mathrm{Cl}), 1.96(\mathrm{Br}), 2.20(\mathrm{I})\right) ;{ }^{[16 e]} \mathrm{R}_{\mathrm{c.u}}=\mathrm{d}(\mathrm{Mo}-\mathrm{Mo}) / \sqrt{ } 2+\mathrm{d}\left(\mathrm{Mo}-\mathrm{X}^{\mathrm{a}}\right)+\mathrm{R}\left(\mathrm{X}^{-}\right)$; $\mathrm{Nb}_{\mathrm{CB}}$ values are calculated taking 20 and $24 \AA^{2}$ extreme values for the transverse cross section of one $\mathrm{CB}$.

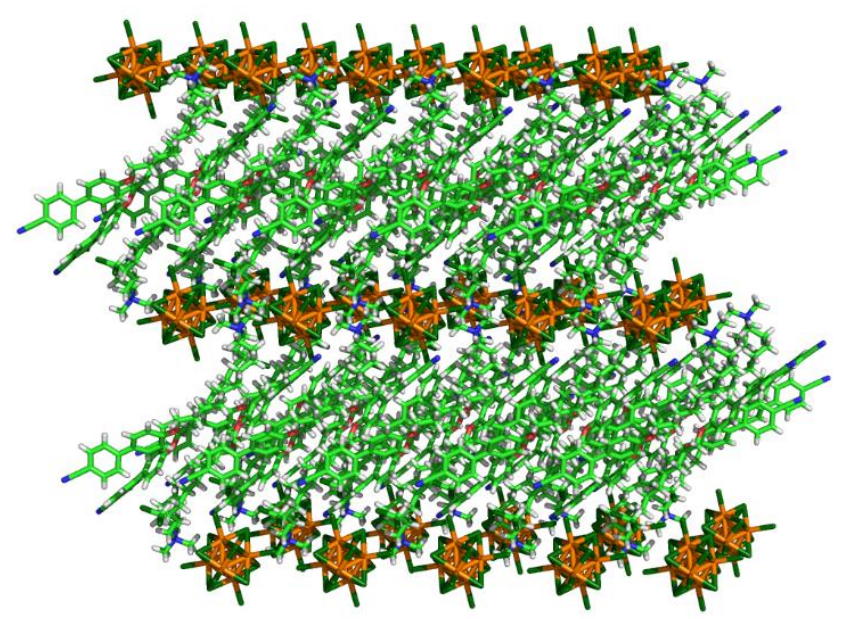

Figure 1. Representation according to single crystal x-ray diffraction data of the layered structure in $\left(\mathrm{Katb}_{2}\left[\mathrm{Mo}_{6} \mathrm{Cl}_{14}\right], 2 \mathrm{CH}_{2} \mathrm{Cl}_{2}\right.$. 
$\mathrm{Kat}^{+}$(Scheme 1) was obtained as its bromide salt form according to reported procedure. ${ }^{56}$ In all cases, a stoichiometric amount of Kat-Br was used to exchange the alkali counter cations associated with the cluster unit. Different solvents were used to realize the metathesis reaction with respect to cluster precursor solubility (see the method part for further details). Hybrid compounds were characterized by ${ }^{1} \mathrm{H}$ NMR, energy dispersive spectroscopy (EDS) and elemental analysis. ${ }^{1} \mathrm{H}$ NMR spectra of hybrids are very similar to the parent organic salt $\mathrm{KatBr}$, a slight shift to higher field of signals corresponding to protons in $\alpha$ position of $\mathrm{N}$ atoms of the ammonium can be observed. The most important shift being of $0.3 \mathrm{ppm}$.

\section{Self-assembling abilities}

Liquid crystalline properties of hybrid compounds were studied by polarized optical microscopy (POM), differential scanning calorimetry (DSC) and small angle x-ray scattering (SAXS). Results are summarized in Table 2. The organic salt Kat-Br with three CB terminated chains, presented a nematic phase at $113^{\circ} \mathrm{C}$ which was converted into a smectic phase on cooling to $103{ }^{\circ} \mathrm{C}$. This transition was clearly seen by POM although DSC thermogram showed only one transition at $113^{\circ} \mathrm{C} .20$ On further cooling the compound passed to a glassy state. POM observations of hybrid compounds deposited between two glass slides were consistent in all cases with the formation of a enantiotropic nematic phase. Compounds Kat2Mo6Cl14, Kat2Mo6Bri8Cla6 and Kat2Mo6Br14, had to be heated up to $180^{\circ} \mathrm{C}$ during the first heating process to melt all crystals, while the isotropic state was reached at $130^{\circ} \mathrm{C}$ for the two compounds containing iodine ligands. On cooling from the isotropic state, some birefringent flashes could be detected at $90^{\circ} \mathrm{C}$ by applying a gentle mechanical stress on the glass slides, however, the LC texture started to be persistent at lower temperatures for most of the compounds except for Kat2[Mo6Br14] and Kat2[Mo6Bri8la6].

Table 2. Phase behaviour and transition temperatures of obtained compounds taken from the $2^{\text {nd }}$ heating and $2^{\text {nd }}$ cooling (only $1^{\text {st }}$ cooling data are shown for $\mathrm{KatBr}$ )

\begin{tabular}{ccc}
\hline & $\mathrm{LC}$ & $\mathrm{T} /{ }^{\circ} \mathrm{C}$ \\
\hline \multirow{5}{*}{$\mathrm{KatBr}^{\mathrm{a}}$} & $\mathrm{I}-\mathrm{N}$ & 113 \\
& $\mathrm{~N}-\mathrm{SmA}$ & $103^{\mathrm{b}}$ \\
& $\mathrm{SmA}-\mathrm{g}$ & 35 \\
& $\mathrm{~g}-\mathrm{N}$ & 43 \\
& $\mathrm{~N}-\mathrm{I}$ & 97 \\
& $\mathrm{I}-\mathrm{N}$ & 71 \\
& $\mathrm{~N}-\mathrm{g}$ & 44 \\
& $\mathrm{~g}-\mathrm{N}$ & 47 \\
$\left.\mathrm{Kat}_{2}\left[\mathrm{Mo}_{6} \mathrm{Cl}_{14}\right] \mathrm{Br}_{8}^{\mathrm{i}} \mathrm{Cl}_{6}^{\mathrm{a}}\right]$ & $\mathrm{N}-\mathrm{I}$ & 99 \\
& $\mathrm{I}-\mathrm{N}$ & 71 \\
& $\mathrm{~N}-\mathrm{g}$ & 46 \\
& $\mathrm{~g}-\mathrm{N}$ & 52 \\
$\mathrm{Kat}_{2}\left[\mathrm{Mo}_{6} \mathrm{Br}_{14}\right]$ & $\mathrm{N}-\mathrm{I}$ & $97^{\mathrm{b}}$ \\
& $\mathrm{I}-\mathrm{N}$ & $87^{\mathrm{b}}$ \\
& $\mathrm{N}-\mathrm{g}$ & 48 \\
& $\mathrm{~g}-\mathrm{N}$ & 44 \\
$\mathrm{Kat}_{2}\left[\mathrm{Mo}_{6} \mathrm{Br}^{\mathrm{i}}{ }_{8} \mathrm{I}_{6}^{\mathrm{a}}\right]$ & $\mathrm{N}-\mathrm{I}$ & $97^{\mathrm{b}}$ \\
& $\mathrm{I}-\mathrm{N}$ & $90^{\mathrm{b}}$ \\
& $\mathrm{N}-\mathrm{g}$ & 40 \\
& $\mathrm{~g}-\mathrm{N}$ & 31 \\
& $\mathrm{~N}-\mathrm{I}$ & $95^{\mathrm{b}}$ \\
$\mathrm{Kat}_{2}\left[\mathrm{Mo}_{6} \mathrm{I}_{14}\right]$ & $\mathrm{I}-\mathrm{N}$ & $78^{\mathrm{b}}$ \\
& $\mathrm{N}-\mathrm{g}$ & 27 \\
\hline
\end{tabular}

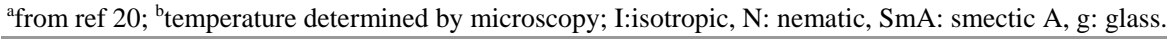

Thus, nematic schlieren textures with two and/or four-brush disclinations were obtained for the majority of hybrids as depicted in Figure 2 and were maintained upon cooling until room temperature showing that the mesophases were freezing into a glass state. All compounds showed qualitatively equivalent DSC thermograms that were in good accordance with POM observations. Although the curves corresponding to the first heating reflect the usual complicated thermal behaviour of supermolecular systems with several endo or exothermic signals, ${ }^{57-60}$ on further heating-cooling cycles the DSC traces appear typically silent with a large glass transition around $50^{\circ} \mathrm{C}$ corresponding to the freezing of the mesophase. For Kat ${ }_{2} \mathrm{Mo}_{6} \mathrm{Cl}_{14}$ and $\mathrm{Kat}_{2} \mathrm{Mo}_{6} \mathrm{Br}_{8}^{\mathrm{i}} \mathrm{Cl}_{6}{ }_{6}$ however, very weak signals at $71^{\circ} \mathrm{C}$ corresponding to the transition between the mesomorphic and isotropic states could be observed either on cooling or heating cycle. The weakness of such signals precludes any quantitative data to be extracted (ESI).

Temperature dependent small angle X-ray scattering experiments are in good accordance with the assignment of the nematic phase. Indeed, after cooling samples from the isotropic state, intense and broad scattering at small angles indicate that there is only a short range periodicity that is typical for nematic phases. They were attributed to the intermolecular short-range interactions that are parallel (32.4 $\AA$ ) and perpendicular (14.5 $\AA$ ) to the molecular long axis, respectively. Note that these data are in good accordance with the length of the molecular hybrid ( $\left.\mathrm{Kat}_{2} \mathrm{Mo}_{6} \mathrm{X}_{8}{ }_{8} \mathrm{X}_{6}{ }_{6}\right)$ and the cluster cross section, respectively. 

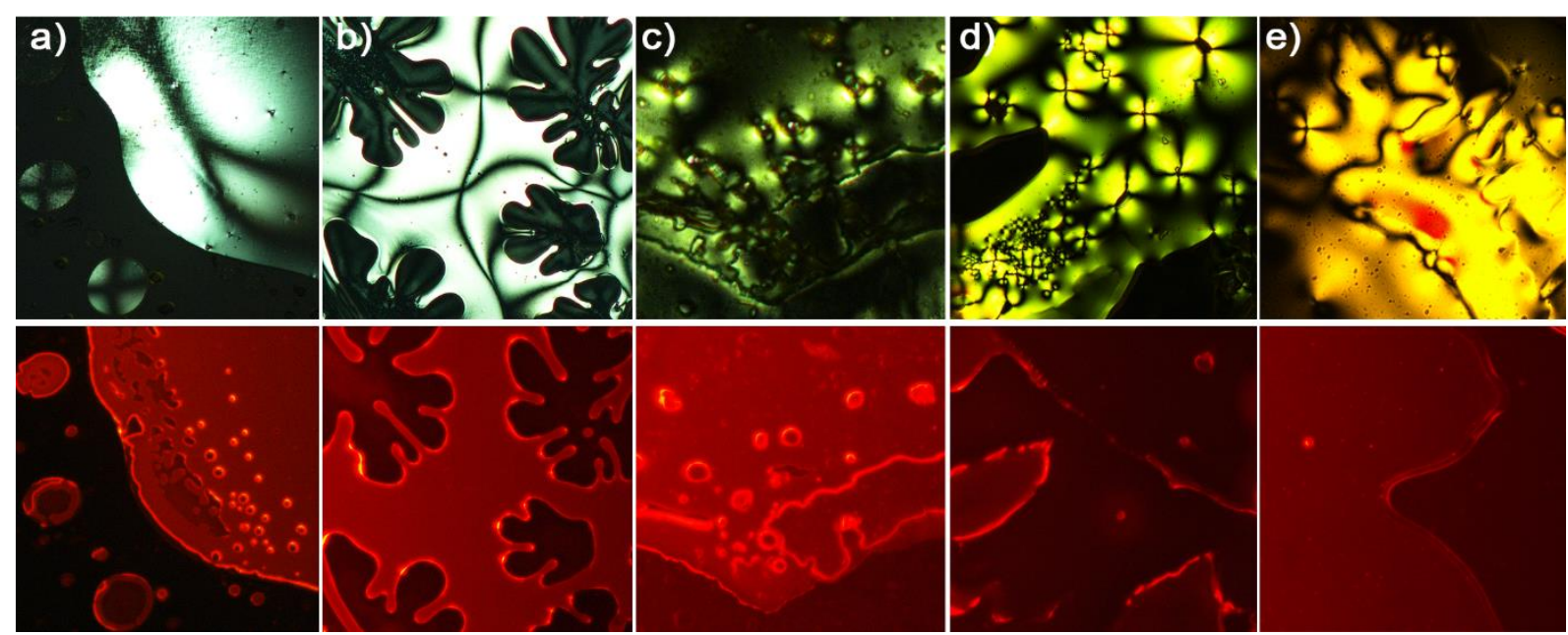

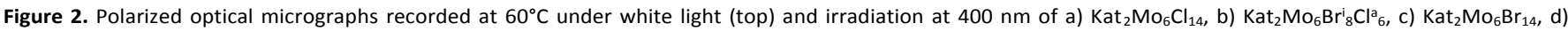
$\left.\mathrm{Kat}_{2} \mathrm{Mo}_{6} \mathrm{Br}_{8}{ }_{1}^{\mathrm{a}}{ }_{6}, \mathrm{e}\right) \mathrm{Kat}_{2} \mathrm{Mo}_{6} \mathrm{I}_{14}$

The pure nematogenic character of hybrids is somehow quite surprising taking into account all the literature dealing with ionically self-assembled hybrid systems. Indeed, our molecular material can be seen as a supermolecular system with terminally attached mesogenic units. In this case, most of the literature reports describe smectic or columnar behaviour, ${ }^{61}$ and indeed, by using an electrostatic approach, L. Wu et al. had to laterally attached mesogen units onto their organic counter-cation to observe nematic phases with polyoxometallate. ${ }^{62}$ Terminally appended mesogenic units leaded in their case only to layered phases. ${ }^{63,64}$ We previously observed the formation of a nematic phase by combining $\mathrm{Kat}^{+}$with $\left[\mathrm{Mo}_{6} \mathrm{Br}_{8}{ }_{8}(\mathrm{CN})_{6}^{\mathrm{a}}\right]^{2-}{ }^{20} \mathrm{However}^{2}$ this phase was observed only on a very short temperature range $\left(7^{\circ} \mathrm{C}\right)$ and immediately followed on cooling by a layered SmA phase. Layered phases were also obtained by replacing the molybdenum cluster with rhenium ones of higher charge $\left(\left[\operatorname{Re}_{6} \mathrm{Se}_{8}^{\mathrm{i}}(\mathrm{CN}){ }_{6}^{\mathrm{a}}\right]^{\mathrm{n}-}\left(\mathrm{with}^{\mathrm{i}} \mathrm{n}=3\right.\right.$ or 4)). In this last case, the supramolecular organization was mainly driven by the organic moieties. This point is also in good accordance with previously reported results. ${ }^{60,61,65}$ Therefore, observing only the formation of one enantiotropic nematic phase, not only for one compound but for an all family is of particular interest taking into account i) the ionic character of the polymolecular building blocks and ii) that the mesogenic units are terminally attached to the supermolecular assembly.

The specific behaviour observed here may be attributed to the balance between the transverse cross section of the organic and the inorganic parts of the material. Indeed, as depicted in Figure 1 which illustrates the molecular arrangement of $\left(\mathrm{Katb}_{2}\left[\mathrm{Mo}_{6} \mathrm{Cl}_{14}\right]\right.$ in its crystalline phase, the decrease of organic fraction compared to the situation in $\mathrm{Kat}_{2}\left[\mathrm{Mo}_{6} \mathrm{Cl}_{14}\right]$ is compensated by a tilt of the organic arms as compared to the normal of the inorganic planes. It results in a lowering of the interlayer distance. In the nematogenic compounds, the intermolecular short range interactions distance parallel to the molecular axis is around $32 \AA$ which is one nanometre longer than the interlayer spacing in (Katb) ${ }_{2}\left[\mathrm{Mo}_{6} \mathrm{Cl}_{14}\right]$. This could be interpreted as a different orientation of the ammonium cations organic arms that should be directed more perpendicularly to the "pseudo inorganic plane" (taking in consideration that $\mathrm{CB}$ units from one hybrid to another are fully interdigitated in order to compensate the transverse cross sections of its organic and inorganic parts within the material). This is in good accordance with the organic volume fraction that increases in this last case as the ammonium cation $\left(\mathrm{Kat}^{+}\right)$bears an additional CB terminated decyloxy chain. Therefore, we may consider that clusters are laying closer one from each other. Anion-anion coulombic repulsion should occur more strongly in this case, especially with halogen atoms in apical position compared to cyano apical ligands, and prevent clusters alignment within one pseudo-layer thus fostering the nematogenic character of hybrids.

\section{Photophysical properties}

As depicted in Figures $\mathbf{2}$ and Figure 3a, irradiation of hybrids with a UV light gives rise to the deep red emission of $\mathrm{Mo}_{6}$ clusters. It is well known that hexanuclear molybdenum clusters are very interesting emissive inorganic species because of the brightness of their emission and their large Stoke shifts that drastically minimizes reabsorption phenomena usually seen with organic entities. Therefore, in principle, a high weight fraction of inorganic content in the hybrid matrix should not affect significantly their ability to emit light. The phosphorescence absolute quantum yield (AQY) of each compound was measured on samples deposited on a quartz cuvette by means of an integrating sphere and compared to the values calculated for their respective precursor (Table 4). Their excitation wavelength dependence was measured for each hybrid between $360 \mathrm{~nm}$ and $500 \mathrm{~nm}$ and are reported in Figure 3b. We noticed only little variation of AQY; highest values were measured for $\mathrm{Kat}_{2} \mathrm{Mo}_{6} \mathrm{Br}_{8}{ }_{8} \mathrm{Cl}_{6}{ }_{6}$ while the lowest one were obtained for $\mathrm{Kat}_{2} \mathrm{Mo}_{6} \mathrm{Br}_{8}{ }^{\mathrm{a}}{ }_{6}^{\mathrm{a}}$. If only few differences were observed between the experimental values of fully brominated or chlorinated clusters and their respective cesium salt, the situation differs significantly for iodinated clusters. Indeed the cationic metathesis in 
these last cases induces a drastic increase of the AQY. This phenomenon is however not yet really understood as many factors can have significant effect on the cluster ability to emit light. For instance, Sokolov et al. investigated the photophysical properties of the $\left(\mathrm{nBu}_{4} \mathrm{~N}\right)_{2} \mathrm{Mo}_{6} \mathrm{X}_{8}{ }_{8}\left(\mathrm{OCOC}_{3} \mathrm{~F}_{7}\right)_{6}^{\mathrm{a}}\left(\mathrm{X}^{\mathrm{i}}=\mathrm{Cl}, \mathrm{Br}, \mathrm{l}\right)$ series and showed that the nature of the inner ligands has a strong effect on the quantum yield value. ${ }^{26} \mathrm{On}$ the other hand, $\mathrm{K}$. Kirakci et al. recently highlighted the tremendous influence of the apical ligand nature on the $\mathrm{QY}$ values in solution for the $\left(\mathrm{nBu}_{4} \mathrm{~N}\right)_{2} \mathrm{Mo}_{6} \mathrm{I}_{8}{ }_{8} \mathrm{X}_{6}^{\mathrm{a}}\left(\mathrm{X}^{\mathrm{a}}=1, \mathrm{OCOCF}_{3}, \mathrm{OCOC}_{3} \mathrm{~F}_{7}\right)$ series. ${ }^{66}$ They also reported some antennae effect by grafting UV absorbing and blue emitting organic moieties like pyrene or anthracene on the apical position of the cluster core. ${ }^{67}$

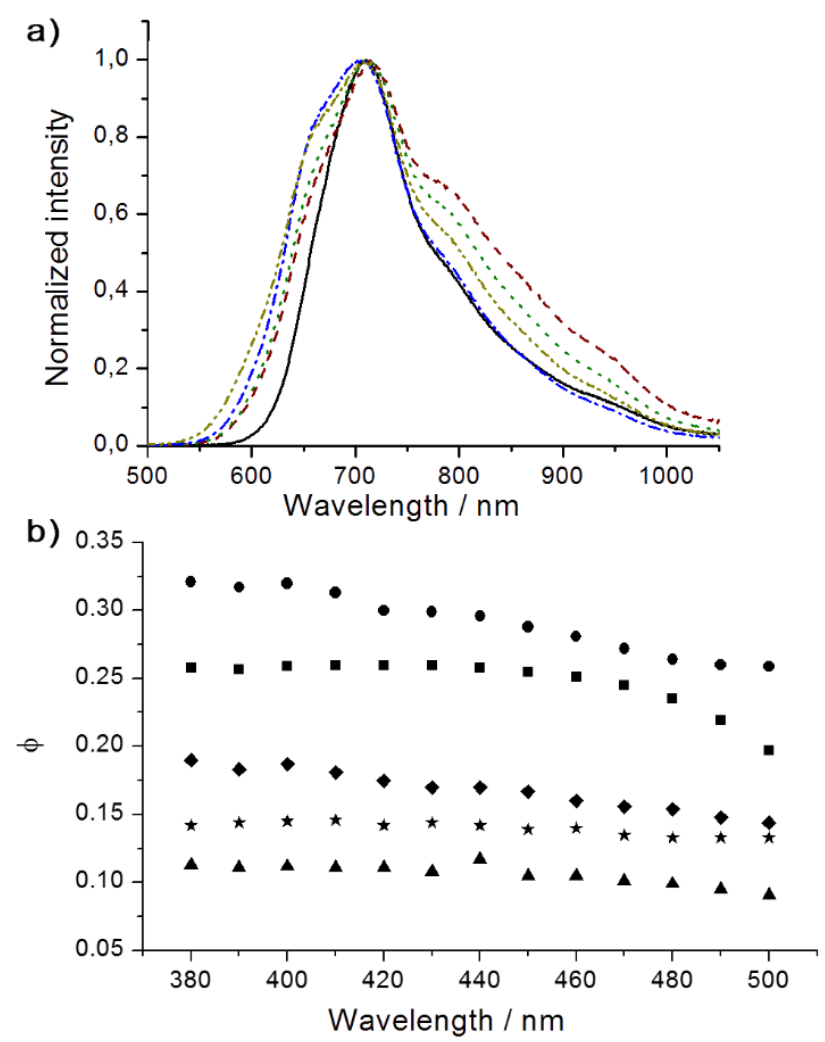

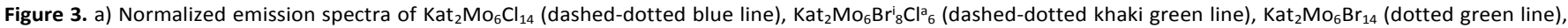

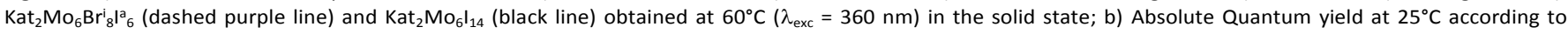
excitation wavelength of $\mathrm{Kat}_{2} \mathrm{Mo}_{6} \mathrm{Cl}_{14}$ (square), $\mathrm{Kat}_{2} \mathrm{Mo}_{6} \mathrm{Br}_{8}^{\mathrm{i}} \mathrm{Cl}_{6}{ }_{6}$ (dot), $\mathrm{Kat}_{2} \mathrm{Mo}_{6} \mathrm{Br}_{14}$ (diamond), $\mathrm{Kat}_{2} \mathrm{Mo}_{6} \mathrm{Br}_{8}^{\mathrm{i}} \mathrm{I}_{6}^{\mathrm{a}}\left(\mathrm{triangle}\right.$ and $\mathrm{Kat}_{2} \mathrm{Mo}_{6} \mathrm{I}_{14}(\mathrm{star}$ ).

Here, we show that the nature of the counter cation has also a great influence on the $\mathrm{Mo}_{6}$ cluster scaffold ability to emit light. Indeed, the CB unit absorbs strongly in the UV area (vide infra) and emits weakly in the blue region. Therefore, an antennae effect from the $C B$ units to the metallic scaffold could be responsible for the enhancement of the cluster luminescence properties. 
Table 4. Kinetic parameters obtained for $\mathrm{Kat}_{2} \mathrm{Mo}_{6} \mathrm{X}_{8}^{\mathrm{i}} \mathrm{X}_{6}^{\mathrm{a}}$ at $60^{\circ} \mathrm{C}$ under $355 \mathrm{~nm}$ irradiation and absolute quantum yields calculated for $\mathrm{Kat}_{2} \mathrm{Mo}_{6} \mathrm{X}_{8}^{\mathrm{i}} \mathrm{X}_{6}^{\mathrm{a}}$ and $\mathrm{Cs}_{2} \mathrm{Mo}_{6} \mathrm{X}_{8}^{\mathrm{i}} \mathrm{X}_{6}^{\mathrm{a}}$ (values in parenthesis) in the solid state.

\begin{tabular}{ccccccc}
\hline & $\mathrm{A}_{1}$ & $\begin{array}{c}\tau_{1} / \\
\mu \mathrm{s}\end{array}$ & $\mathrm{A}_{2}$ & $\begin{array}{c}\tau_{2} / \\
\mu \mathrm{s}\end{array}$ & $\mathrm{R}^{2}$ & $\Phi_{\mathrm{em}}$ \\
\hline $\mathrm{Kat}_{2}\left[\mathrm{Mo}_{6} \mathrm{Cl}_{14}\right]$ & 0.36 & 5,8 & 0.64 & 48 & 0.9994 & 0.24 \\
& & & & & & $(0.24)$ \\
$\mathrm{Kat}_{2}\left[\mathrm{Mo}_{6} \mathrm{Br}_{8}^{\mathrm{i}} \mathrm{Cl}_{6}{ }_{6}\right]$ & 0.43 & 5.3 & 0.57 & 49 & 0.9986 & 0.32 \\
& & & & & & $(0.21)$ \\
$\mathrm{Kat}_{2}\left[\mathrm{Mo}_{6} \mathrm{Br}_{14}\right]$ & 0.51 & 5.3 & 0.49 & 44 & 0.9897 & 0.18 \\
& & & & & & $(0.14)$ \\
$\mathrm{Kat}_{2}\left[\mathrm{Mo}_{6} \mathrm{Br}_{8}{ }^{\mathrm{i}}{ }_{6}{ }_{6}\right]$ & 0.49 & 3.4 & 0.51 & 21 & 0.9963 & 0.11 \\
& & & & & & $(0.03)$ \\
$\mathrm{Kat}_{2}\left[\mathrm{Mo}_{6} \mathrm{I}_{14}\right]$ & 0.45 & 2.8 & 0.55 & 29 & 0.9963 & 0.15 \\
& & & & & & $(0.01)$ \\
\hline
\end{tabular}

Nonetheless, these measurements also show that using a commercial blue light emitting diode (which emission wavelength lies around $405 \mathrm{~nm}-430 \mathrm{~nm}$ ) to excite our materials will not affect its ability to emit light which is of peculiar interest in terms of application prospects. One should however take also into account the molar absorption coefficients of such species as a delicate balance must be found between photon absorption and quantum yield value to visualize properly the red emission.

Absorption measurements were thus realized on all samples in solution and are reported in ESI (Fig S13). Absorption spectra are mainly composed by the $\mathrm{Kat}^{+}$absorption bands that contains the highly UV-absorbing CB units. A careful look in the $400-500 \mathrm{~nm}$ area shows few differences due to the nature of the clusters inner and apical ligands. These differences are in good accordance with the already reported clusters absorption spectra especially in the case of $\mathrm{Kat}_{2} \mathrm{Mo}_{6} \mathrm{X}_{14}$ with $\mathrm{X}=\mathrm{Cl}, \mathrm{Br}, \mathrm{I}{ }^{32,66}$

Although photophysical properties of transition metal clusters are well documented, usual studies are performed at $25^{\circ} \mathrm{C}$ or $-196^{\circ} \mathrm{C}$ to minimize or nearly suppress non radiative decay. Therefore, nothing is known about their behaviour at higher temperature than $25^{\circ} \mathrm{C}$. Indeed, if one envisions the use of such material in real devices, their working temperature (between $50^{\circ} \mathrm{C}$ and $85^{\circ} \mathrm{C}$ ) must be taken into account and luminescence characterization should be realized, when possible, within this temperature range to get a realistic view of the material potential. Therefore, emission lifetime measurements were realized at $60^{\circ} \mathrm{C}$ i.e. within the nematic LC phase for all hybrids on samples deposited on a quartz slide. The spectroscopic $\left(\lambda_{\text {em }}\right)$ and photophysical parameters (emission lifetime (amplitude $\left.=A_{n}\right)=\tau_{n}(n=2)$ ) calculated at $60^{\circ} \mathrm{C}$ are summarized in Table 4 . The data were fitted to a two exponential decay and the goodness of fit judged by the $\mathrm{R}^{2}$ values. All samples show a biexponential behaviour with lifetimes in the range of few microseconds. This could be explained by the fact that measurements being realized at higher temperature than the ones previously used for such studies, new desexcitation pathways are likely to proceed and may end up on new emissive states.

This point is corroborated by the calculated lifetime values that are significantly shorter than the one usually calculated for $\left[\mathrm{Mo}_{6} \mathrm{X}_{14}\right]^{2-}$ derivatives. ${ }^{25,28}$ Indeed, Maverick et al. reported a monoexponential behaviour at $27^{\circ} \mathrm{C}$ in $\mathrm{CH}_{3} \mathrm{CN}$ solution for $\left(\mathrm{nBu}_{4} \mathrm{~N}\right)_{2} \mathrm{Mo}_{6} \mathrm{Cl}_{14}$ and $\left(\mathrm{nBu}_{4} \mathrm{~N}\right)_{2} \mathrm{Mo}_{6} \mathrm{Br}_{14}$ with lifetime values of $180 \mu$ s and $130 \mu$ sespectively, ${ }^{25}$ while a lifetime value of $65 \mu$ s was obtained in $\mathrm{CH}_{3} \mathrm{CN}$ solution for $\left(\mathrm{nBu}_{4} \mathrm{~N}\right)_{2} \mathrm{Mo}_{6} \mathrm{l}_{14} .{ }^{68}$ However, we should emphasize at this point that if $\left[\mathrm{Mo}{ }_{6} \mathrm{X}_{14}\right]^{2-}(\mathrm{X}=\mathrm{Cl}, \mathrm{Br}, \mathrm{I}) \mathrm{cluster}$ core photophysical properties have been well studied, nothing is known experimentally about the one of $\left[\mathrm{Mo}_{6} \mathrm{Br}^{\mathrm{i}} \mathrm{X}_{8}{ }_{6}\right]^{2-}$ with $\mathrm{Xa}^{2}=$ $\mathrm{Cl}$, I. It appears that, as predicted from quantum calculations by R. Ramirez-Tagle and R. Arratia-Pérez, ${ }^{69}$ these clusters behave in the same way as their monohalogenated analogues with emission maxima at the same wavelength, AQY and lifetimes value in the same range.

\section{Miscibility studies}

Despite the nematic nature of the observed LC phases which, in principle should show high fluidity, hybrids remain very viscous. Therefore, their introduction in pure form in electro-controlled LC devices does not lead to operational systems in which the molecular orientation is driven by application of an electric field. To increase their fluidity, they may be combined with commercially available highly fluidic liquid crystals with the prerequisite that resulting mixtures remain fully homogeneous. Therefore, we first investigated the miscibility of $\mathrm{Kat}_{2} \mathrm{Mo}_{6} \mathrm{X}_{14}(\mathrm{X}=\mathrm{Cl}, \mathrm{Br}, \mathrm{I})$ with commercially available nematic LC E44 and the influence of the hybrid concentration on the nematic to isotropic transition temperature (Table 5). Homogeneous mixtures were obtained by dissolving both components in a small amount of $\mathrm{CH}_{2} \mathrm{Cl}_{2}$ followed by sonication for 30 min, solvent evaporation and drying. All mixtures thermal behaviour were investigated by POM and DSC and compared to the one of pure compounds. DSC thermogram of E44 contains only one very broad transition both on heating and cooling cycles, extending on cooling from 107.5 ${ }^{\circ} \mathrm{C}$ to $88.8^{\circ} \mathrm{C}$. The onset of this isotropic to LC transition shows only little variation as a function of increasing clustomesogens concentration, indicating that they are essentially miscible with the commercial matrix (see ESI Figures S10-S12 for 
thermograms). ${ }^{70}$ Indeed, no cluster aggregation was detected by microscopy under UV irradiation as depicted in Figure 4 which presents polarized optical micrographs (integration time: $1 \mathrm{~s}$ ) of different $10 \mathrm{wt} \%$ mixtures taken at $80^{\circ} \mathrm{C}$. The differences in red intensity are due to the different cluster core absorption coefficients at the irradiation wavelength and illustrate that iodide clusters present the best compromise between their absorption abilities and their AQY value in terms of colour rendering. Surprisingly, while all mixtures have a similar thermal behaviour, introducing 10 wt\% of $\mathrm{Kat}_{2} \mathrm{Mo}_{6} \mathrm{Br}_{14}$ in $\mathrm{E}_{44}$ induces on the DSC thermogram a narrowing of the isotropic to nematic transition that still remains unexplained and that disappears at 20 wt\% of clustomesogen content (the phenomenon is already perceptible for the $5 \mathrm{wt} \%$ mixture but a weak transition signal can still be detected around $105^{\circ} \mathrm{C}$ ). We also observed for all mixtures on cooling the appearance of a weak first order transition around $70^{\circ} \mathrm{C}$ that may correspond to the isotropic to nematic transition of functionalized clusters.

Table 5. Isotropic to nematic transition temperature in ${ }^{\circ} \mathrm{C}$ of mixtures of $\mathrm{E} 44$ and hybrids at various concentration determined by DSC.

\begin{tabular}{cccc}
\hline $\begin{array}{c}\text { Concentration } \\
\text { (wt } \% \text { ) }\end{array}$ & $\mathrm{Kat}_{2} \mathrm{Mo}_{6} \mathrm{Cl}_{14}$ & $\mathrm{Kat}_{2} \mathrm{Mo}_{6} \mathrm{Br}_{14}$ & $\mathrm{Kat}_{2} \mathrm{Mo}_{6} \mathrm{I}_{14}$ \\
\hline 0 (pure E44) & 107.5 & 107.5 & 107.5 \\
1 & 106.7 & 107.9 & 107.1 \\
5 & 106.3 & 105.5 & 107.5 \\
10 & 107.8 & 94.4 & 106.8 \\
20 & 99.9 & 107.0 & 102.1 \\
100 & 71 & 87 & 78 \\
\hline
\end{tabular}
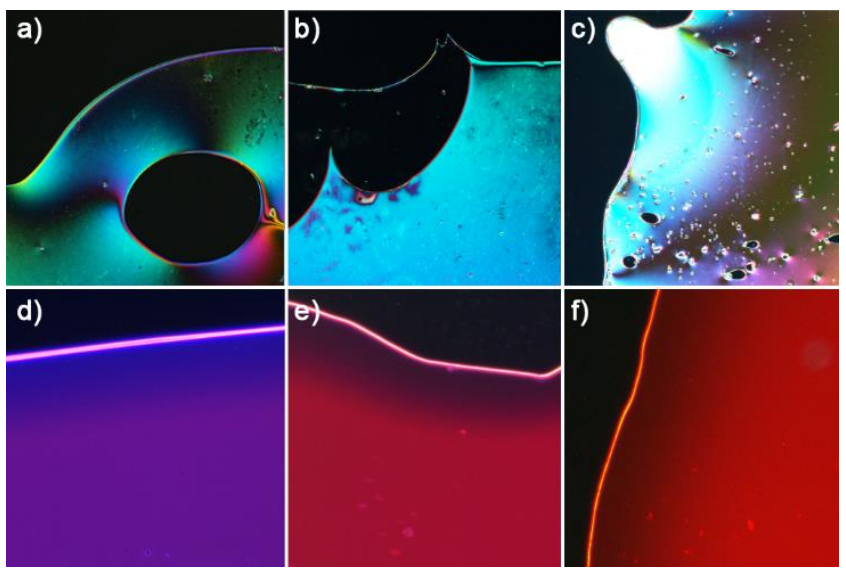

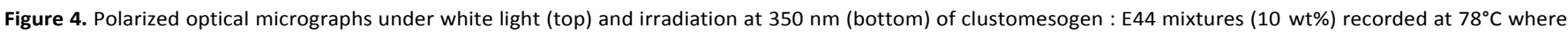
clustomesogen corresponds to $\mathrm{Kat}_{2} \mathrm{Mo}_{6} \mathrm{Cl}_{14}$ (left), $\mathrm{Kat}_{2} \mathrm{Mo}_{6} \mathrm{Br}_{14}$ (middle), $\mathrm{Kat}_{2} \mathrm{Mo}_{6} \mathrm{I}_{14}$ (right).

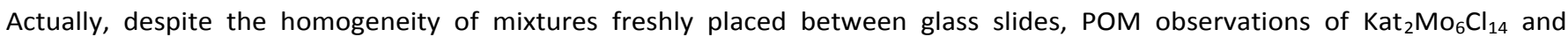
$\mathrm{Kat}_{2} \mathrm{Mo}_{6} \mathrm{Br}_{14}$ containing samples stored for several hours at room temperature revealed phase segregation phenomena. Only mixtures containing $\mathrm{Kat}_{2}\left[\mathrm{Mo}_{6} \mathrm{I}_{14}\right]$ showed sufficient stability (over several days) to be incorporated in a LC cell (heating the mixture above its clearing temperature allows recovering a full homogeneity). Temperature dependent SAXS experiments were performed with the Kat ${ }_{2} \mathrm{Mo}_{6} \mathrm{l}_{14}: \mathrm{E} 4410 \mathrm{wt} \%$ mixture at several temperatures on cooling from the isotropic state (Figure S20) but did not lead to clear conclusions regarding an eventual cluster aggregation as diffractograms were all similar and in good agreement with the nematic nature of the mixture.

\section{Integration into electroswitchable device}

Although clusters present strong emission in the red-NIR, we observed that a $10 \mathrm{wt} \%$ amount of clustomesogen in the commercial LC was a minimum value to properly visualize a red-NIR luminescence signal at $80^{\circ} \mathrm{C}$ (which roughly corresponds to the temperature generated by the backlights within LCD devices). Thus, $\mathrm{Kat}_{2} \mathrm{Mo}_{6} \mathrm{I}_{14}: \mathrm{E} 4410 \mathrm{wt} \%$ mixture was inserted by capillarity in a $5 \mu \mathrm{m}$ thick LC planarily-aligned cell. The integrated photoluminescence signal upon continuous irradiation at $400 \mathrm{~nm}$ was monitored at $80^{\circ} \mathrm{C}$ upon application (on state) or not (off state) of a 30V AC current on the LC cell. Figure $\mathbf{5}$ shows that application of a voltage on this cell induces a drastic change in the photoluminescence intensity of about $52 \%$ at $80^{\circ} \mathrm{C}$. 

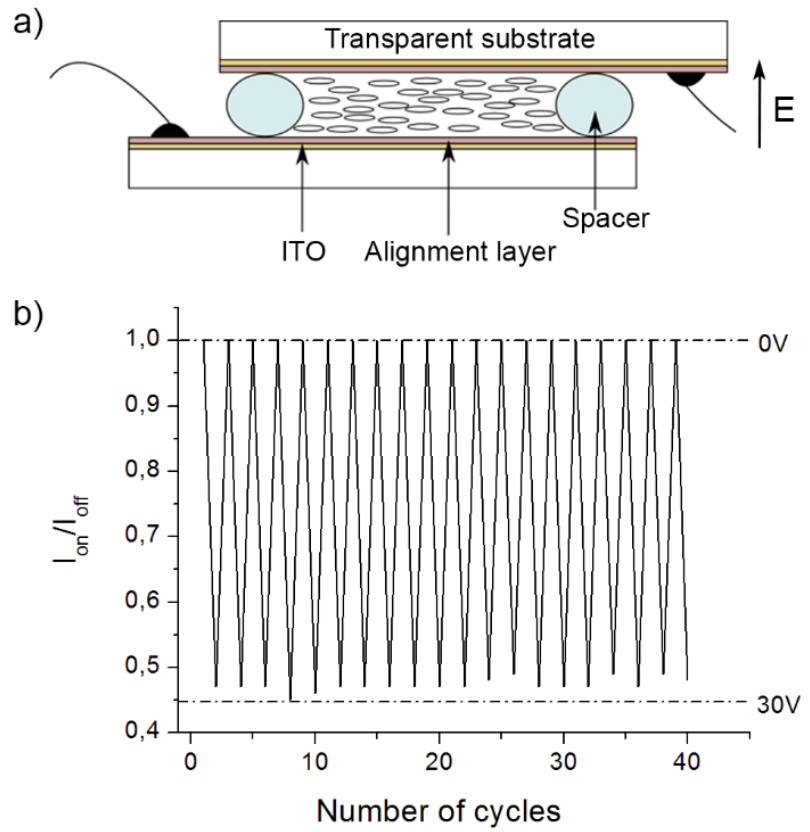

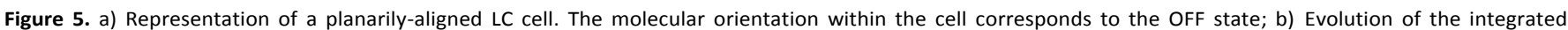

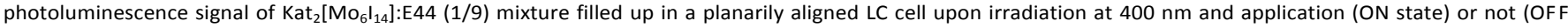
state) of a $30 \mathrm{~V} \mathrm{AC}$ voltage at $78^{\circ} \mathrm{C}$.

The same experiment performed at $25^{\circ} \mathrm{C}$ gave only rise to a modulation of around $20 \%$ of the photoluminescence signal, ESI Figure S20. This difference could eventually be explained by the microsegregation of $\mathrm{Kat}_{2} \mathrm{Mo}_{6} \mathrm{I}_{14}$ in the host matrix. This phenomenon would increase locally the viscosity of the mixture preventing $\mathrm{Kat}_{2} \mathrm{Mo}_{6} \mathrm{l}_{14}$ microagregates to properly react to the electric field. This should induce in principle a decrease of the photoluminescence contrast. The exact origin of this reversible switch in the luminescence intensity may be imparted to many cooperating (birefringence of the LC host, birefringence of the hybrid, emission anisotropy...) and is not yet fully understood. However, several observations can be made at this stage: i) E44 was chosen for its high birefringence $(\Delta n=0.26$ at $\lambda=589 \mathrm{~nm}$ ) but can only be partially responsible for the intensity modulation that is about $52 \%$; ii) as the switch is fully reversible, clustomesogens appear to be stable under voltage application despite their ionic character (no apparent charge separation); iii) this stability implies also that the applied electric field is not high enough to oxidize or reduce the metal clusters from a luminescent to a non-luminescent form; iv) luminescence properties are only due to anionic cluster moieties. As these entities are isotropic, the use of an electric field to align the molecules should not modify their ability to emit light. Therefore, according to our observations, it seems that the all hybrid supramolecular compounds has to be taken into account when one consider the emission properties of such system in the LC phase. In this context, one might also consider the ability of the CB units to act as antenna with the metallic cluster. Indeed, their orientation in the LC cell influences not only their ability to absorb incident photons ${ }^{71}$ but also their ability to emit. Therefore, their ability to sensitize the cluster emission should be enhanced in a particular direction inducing such high difference in the cluster luminescence band intensity.

\section{Conclusions}

Five hybrid compounds containing the same mesomorphic organic cation and different octahedral molybdenum metallic scaffold have been synthesized by using electrostatic interactions and show an unusual nematic liquid crystal behaviour. It appears that the volumic fraction of the organic phase is just sufficient to compensate the one of its inorganic counterpart. As a result, the phase segregation usually observed in this type of material is not observed promoting the nematogenic behaviour of the material. Luminescence studies performed in the LC phase show that the intrinsic properties of the parent nanocluster are preserved or enhanced after hybridization with the LC organic counter-cations. This phenomenon is also observed when the supermolecules are mixed with a commercially available LC mixture that is used to increase their fluidity. In that way, a stable and homogeneous mixture containing $\mathrm{Kat}_{2}\left[\mathrm{Mo}_{6} \mathrm{l}_{14}\right]$ at $10 \mathrm{wt} \%$ in $\mathrm{E} 44$ could be inserted in a planarily aligned LC cell. Application of a voltage on the cell under continuous irradiation at $400 \mathrm{~nm}$ gives a perceptible modulation of the photoluminescence intensity of around $52 \%$ that is much higher than the birefringence of the LC host. A possible explanation of this phenomenon arises from the ability of CB units to act as anisotropic sensitizer of the isotropic metallic cluster luminescence. Finally, this work present the first device containing 
nematic clustomesogens whose luminescence is strongly and reversibly modulated upon application of an electric field. Such demonstrator opens fascinating perspectives in the design of optoelectronic devices built up from stable red or red-NIR emitters.

\section{Experimental}

NMR spectra were recorded on a Brucker 400P. All signals were referenced to the methyl signals of TMS at $\delta=0$ ppm. UV-Vis absorption measurements were performed on a Varian Cary 5000 UV-Vis-NIR spectrophotometer. Luminescence spectra were recorded with an ocean optic QE6500 photodetector mounted on the polarized optical microscope described below. Elemental Analysis were performed at the CRMPO with a Microanalyser Flash EA1112 CHNS/O Thermo Electron. Energy dispersive spectroscopy (EDS) was performed at CMEBA on a JEOL 6400 scanning electron microscope equipped with a XEDS Oxford field spectrometer. Polarized optical Microscopy and temperature dependent relative irradiance measurements were realized with a Nikon 80i polarized microscope equipped with a Linkam LTS420 hot stage, a Nikon Intensilight irradiation source, a Nikon DS-FI2 digital camera and an ocean optics QE6500 photodetector connected by optical fibre. In order to take into account the nonlinear sensitivity of the set up, it was calibrated with an Ocean Optics HL-2000-CAL Calibrated Tungsten Halogen Light Source. Two optical filters were used to select the excitation wavelength: either with a bandwidth: 330-380 nm or with a bandwidth $380-420 \mathrm{~nm}$. DSC measurements were realized at $10 \mathrm{~K} \cdot \mathrm{min}^{-1}$ with a DSC $200 \mathrm{F3}$ Maia NETSCH apparatus. X-Ray spectra are given as the scattering intensity versus the wavevector transfer $q=4 \pi \sin (\theta)^{-1}\left(\AA^{-1}\right)$. X-ray scattering experiments were performed using a FR591 Bruker AXS rotating anode $X$-ray generator operated at $50 \mathrm{kV}$ and $50 \mathrm{~mA}$ with monochromatic Cu K $\alpha$ radiation $(\lambda=1.541 \AA$ ) and point collimation. X-ray patterns were collected with a Mar345 Image-Plate detector (Marresearch, Norderstedt, Germany). The monochromatic $\mathrm{Cu} K \alpha$ radiation $(\lambda=1.541 \AA$ ) was directed with a $350 \mu \mathrm{m} \times 350 \mu \mathrm{m}$ focal spot at $320 \mathrm{~mm}$ by a double reflection on an elliptic cross multilayer Montel mirror (Incoatec, Geesthacht, Germany). The beam was defined under vacuum by four motorized carbon-tungsten slits (JJ-Xray, Roskilde, Denmark) positioned in front of the mirror ( $500 \mu \mathrm{m} \times 500 \mu \mathrm{m})$. Four additional guard slits $(600 \mu \mathrm{m} \times 600 \mu \mathrm{m})$ were placed at the focal point with a $220 \mathrm{~mm}$ slit separation distance. The flux after the output mica windows was $3 \times 10^{8}$ photons/s. A $2 \mathrm{~mm}$ diameter square lead beam stop was placed under a vacuum at $270 \mathrm{~mm}$; afterward, the sample and the detector were positioned at $420 \mathrm{~mm}$. The X-ray patterns were therefore recorded for a range of reciprocal spacing $q=4 \pi \sin \theta / \lambda$ from 0.03 to $1.56 \AA^{-1}$, where $\theta$ is the diffraction angle. The repetition distances $d=2 \pi / q$ should be between 200 and 4.0 A. The samples were placed into $1.5 \mathrm{~mm}$ glass capillaries (Glas W.Müller, Germany) and introduced into a homemade capillary holder, which can maintain up to 20 capillaries at a controlled temperature. We use the programs Fit $2 \mathrm{D}$ and IgorPro to treat the data. ${ }^{72}$ The liquid crystal cells are made up by two glass plates covered by a $100 \Omega$ / square Indium Tin Oxide transparent electrode. A thin layer of polyimide wass deposited by spin-coating on each substrate and cured at $180^{\circ} \mathrm{C}$. Both plates were rubbed in order to give a homogeneous alignment direction to the liquid crystal. A gasket of glue was deposited on the edge of one plate by a liquid dispenser and then, they were assembled and pressed. Spacers of $5 \mu \mathrm{m}$ were dispersed in the glue to force a gap of $5 \mu \mathrm{m}$ between the two plates. After UV curing of the gasket, the cells were filled by capillarity with liquid crystal mixture. Lifetime measurements were performed using APD110A Thorlabs Si avalanche photodiode and MPL-F-355 CNI 355 Q-switched laser with 7ns - $1 \mu \mathrm{J}$ pulses and $6 \mathrm{kHz}$ repetition rate.Traces were recorded using Lecroy 12 bit HDO4022 $200 \mathrm{MHz}$ oscilloscope with 1000 averaging. Electroswitchable device integrated luminescence was measured using PDA36A-EC Thorlabs Si avalanche photodiode and 405nm $50 \mathrm{~mW}$ Oxxius laser diode circularly polarized impinging at $\sim 15^{\circ}$ incidence. For latter both measurements, luminescence was collected at normal incidence with numerical aperture of $\sim 0.16$ using parabolic mirrors, spectrally filtered with a high pass $500 \mathrm{~nm}$ filter and focused on the detector using another parabolic mirror. The device temperature was controlled using a MR-hei-TecHeidolph hotplate. Temperature was controlled with a $2^{\circ} \mathrm{C}$ uncertainty. The luminescence quantum yields in the solid state were measured with a C9920-03 Hamamatsu system equipped with a $150 \mathrm{~W}$ xenon lamp, a monochromator, a Spectralon integrating sphere and a PMA-12 photomultiplier.

\section{Synthesis}

$\mathrm{Cs}_{2} \mathrm{Mo}_{6} \mathrm{Cl}_{14},{ }^{51} \mathrm{Cs}_{2} \mathrm{Mo}_{6} \mathrm{Br}_{14},{ }^{54} \mathrm{Cs}_{2} \mathrm{Mo}_{6} \mathrm{I}_{14},{ }^{54}$ bis (w-[4-(4'-cyanobiphenylyl)oxy]decyl]dimethylammonium bromide (KATb-Br) ${ }^{56}$ and tris (w-[4-(4'-cyanobiphenylyl)oxy]decyl] methylammonium bromide (KAT-Br) ${ }^{55}$ were obtained by reported procedure with conform analytical data. Starting materials were purchased from Acros, Alfa Aesar and Aldrich, and used without further purification unless otherwise stated.

$\mathbf{K A T b}_{2}\left[\mathrm{Mo}_{6} \mathrm{Cl}_{14}\right]$ : To a pale yellow water solution of $\mathrm{Cs}_{2} \mathrm{Mo}_{6} \mathrm{Cl}_{14}\left(0.089 \mathrm{~g}, 0.067 \mathrm{mmol}\right.$ of cluster in $\left.5 \mathrm{ml} \mathrm{H}_{2} \mathrm{O}\right)$ was added a solution of bisKAT-Br in hot ethanol $(0.103 \mathrm{~g}, 0.13 \mathrm{mmol}$ in $5 \mathrm{ml}$ ). A light yellow precipitate formed immediately. The mixture was refluxed for one hour under stirring to complete the reaction. The desired compound was obtained by filtration, washed with water and hot ethanol 3 times. Single crystals were obtained by slow evaporation of compound dissolved in a minimum of dichloromethane. ${ }^{1} \mathrm{H}$ NMR (300 MHz, $\mathrm{CD}_{2} \mathrm{Cl}_{2}$ ): 1.2.-1.9 (32 H, m), 3.28-3.31 (10 H wide band), 3.99-4.04 (4 H, t), 6.99-7.02 (4 H, d), 7.45-7.55 (4 H, d), 7.66-7.73 (8 H, m). EDS: Mo : $\mathrm{Cl} 6$ : 14.08, no bromine, no cesium. (CCDC 1045821).

$\mathrm{Kat}_{2} \mathrm{Mo}_{6} \mathrm{Cl}_{14}$ : A solution of $\mathrm{Cs}_{2} \mathrm{Mo}_{6} \mathrm{Cl}_{14}(0.089 \mathrm{~g}, 0.067 \mathrm{mmol})$ in acetone was added dropwise to a solution of Kat- $\mathrm{Br}(0.150 \mathrm{~g}, 0.13$ $\mathrm{mmol}$ ) in dichloromethane. A white precipitate formed instantaneously. The mixture was stirred at reflux for $1 \mathrm{~h}$ and the white 
precipitate filtered through Celite ${ }^{\oplus}$. The solvent was evaporated to afford yellow solid. ${ }^{1} \mathrm{H}-\mathrm{NMR}(300 \mathrm{MHz}, \mathrm{CDCl} 3): 1.34-1.39(72 \mathrm{H}$, $\mathrm{m}), 1.71-1.83(24 \mathrm{H}, \mathrm{m}), 2.94(6 \mathrm{H}, \mathrm{s}), 3.10(12 \mathrm{H}, \mathrm{m}), 4.00(12 \mathrm{H}, \mathrm{t}, \mathrm{J}=6.6 \mathrm{~Hz}), 6.99\left(12 \mathrm{H}_{\mathrm{Ar}}, \mathrm{d}, \mathrm{J}=8.7 \mathrm{~Hz}\right), 7.53(12 \mathrm{H}$ Ar, d, J = 8.7 Hz), $7.66\left(24 \mathrm{H}_{\mathrm{Ar}}, \mathrm{q}, \mathrm{J}=8.4 \mathrm{~Hz}\right)$. EA: Found: $\mathrm{C}, 53.07 ; \mathrm{H}, 5.69 ; \mathrm{N}, 3.36 \% \mathrm{C}_{140} \mathrm{H}_{174} \mathrm{~N}_{8} \mathrm{O}_{6} \mathrm{Cl}_{14} \mathrm{Mo}_{6} . \mathrm{H}_{2} \mathrm{O}$ requires $\mathrm{C}, 53.28 ; \mathrm{H}, 5.62 ; \mathrm{N}, 3.55$. EDS: Mo: 29.48; $\mathrm{Cl}$ : 68.06; no bromine, no cesium.

$\mathrm{Kat}_{2} \mathrm{Mo}_{6} \mathrm{Br}_{8}{ }_{8} \mathrm{Cl}_{6}{ }_{6}: \mathrm{Cs}_{2} \mathrm{Mo}_{6} \mathrm{Br}_{8}{ }_{8} \mathrm{Br}^{\mathrm{a}}{ }_{6}(440 \mathrm{mg}, 0.224 \mathrm{mmol})$ and $\mathrm{AgBF}_{4}$ (403 mg, $1.45 \mathrm{mmol}$ ) were introduced into a schlenck tube together with $20 \mathrm{~mL}$ of an acetone/ethanol (1/1) solution. This solution was stirred 15 hours in the dark. After filtration of the AgBr precipitate, an ethanol solution of $\mathrm{CsCl}(2.24 \mathrm{mmol}, 376 \mathrm{mg}$ in $5 \mathrm{ml})$ was added to the filtrate. The mixture was stirred for $24 \mathrm{~h}$ in the dark at $25^{\circ} \mathrm{C}$. After evaporation of solvent to dryness, the solid residue was extracted with $30 \mathrm{ml}$ of dry acetone. After filtration, this acetone solution was further dried to give $\mathrm{Cs}_{2} \mathrm{Mo}_{6} \mathrm{Br}_{8}{ }_{8} \mathrm{Cl}_{6}{ }_{6}$ as a polycrystalline solid. Then, the same method as previously described was used with $\mathrm{Cs}_{2} \mathrm{Mo}_{6} \mathrm{Br}_{8}{ }_{8} \mathrm{Cl}_{6}{ }_{6}(0.034 \mathrm{~g}, 0.02 \mathrm{mmol})$ and $\mathrm{Kat}-\mathrm{Br}(0.05 \mathrm{~g}, 0.045 \mathrm{mmol})$. The product was obtained as an orange solid. ${ }^{1} \mathrm{H}-\mathrm{NMR}\left(300 \mathrm{MHz}, \mathrm{CDCl}_{3}\right)$ : 1.34-1.39 $(72 \mathrm{H}, \mathrm{m}), 1.71-1.83(24 \mathrm{H}, \mathrm{m}), 3.08(6 \mathrm{H}, \mathrm{s}), 3.23(12 \mathrm{H}, \mathrm{m}), 4.00(12 \mathrm{H}, \mathrm{t}, \mathrm{J}=6.6$ $\mathrm{Hz}), 6.99\left(12 \mathrm{H}_{\mathrm{Ar}}, \mathrm{d}, \mathrm{J}=8.7 \mathrm{~Hz}\right), 7.53\left(12 \mathrm{H}_{\mathrm{Ar}}, \mathrm{d}, \mathrm{J}=8.7 \mathrm{~Hz}\right), 7.66\left(24 \mathrm{H}_{\mathrm{Ar}}, \mathrm{q}, \mathrm{J}=8.4 \mathrm{~Hz}\right)$. EA: Found: C, 48.65; H, 5.18; $\mathrm{N}, 3.59 \%$ $\mathrm{C}_{140} \mathrm{H}_{174} \mathrm{~N}_{8} \mathrm{O}_{6} \mathrm{Cl}_{6} \mathrm{Br}_{8} \mathrm{Mo}_{6}$ requires $\mathrm{C}$, 48.15; $\left.\mathrm{H}, 5.02 ; \mathrm{N}, 3.21\right)$. EDS: Mo: 30.51; $\mathrm{Cl}$ : 32.68; $\mathrm{Br}$ : 36.59 \%; no cesium.

$\mathrm{Kat}_{2} \mathrm{Mo}_{6} \mathrm{Br}_{14}$ : The same method as previously described was used with $\mathrm{Cs}_{2} \mathrm{Mo}_{6} \mathrm{Br}_{14}(0.12 \mathrm{~g}, 0.067 \mathrm{mmol})$ and $\mathrm{Kat}-\mathrm{Br}(0.150 \mathrm{~g}, 0.13$ $\mathrm{mmol})$. The product was obtained as an orange oil.

${ }^{1} \mathrm{H}-\mathrm{NMR}\left(300 \mathrm{MHz} \mathrm{CDCl}_{3}\right): 1.34-1.39(72 \mathrm{H}, \mathrm{m}), 1.71-1.83(24 \mathrm{H}, \mathrm{m}), 3.10(6 \mathrm{H}, \mathrm{s}), 3.23(12 \mathrm{H}, \mathrm{m}), 4.00(12 \mathrm{H}, \mathrm{t}, \mathrm{J}=6.6 \mathrm{~Hz}), 6.99(12 \mathrm{H}$ Ar, $\mathrm{d}, \mathrm{J}=8.7 \mathrm{~Hz}), 7.53\left(12 \mathrm{H}_{\mathrm{Ar}}, \mathrm{d}, \mathrm{J}=8.7 \mathrm{~Hz}\right), 7.66\left(24 \mathrm{H}_{\mathrm{Ar}}, \mathrm{q}, \mathrm{J}=8.4 \mathrm{~Hz}\right)$. EA: Found: $\mathrm{C}, 45.19 ; \mathrm{H}, 4.77 ; \mathrm{N} 3.00 \% \mathrm{C}_{140} \mathrm{H}_{174} \mathrm{~N}_{8} \mathrm{O}_{6} \mathrm{Br}_{14} \mathrm{Mo}_{6}$ requires $\mathrm{C}, 44.73 ; \mathrm{H}, 4.67 ; \mathrm{N}, 2.98$. EDS: Mo: 37.72; $\mathrm{Br}$ : $62.2 \%$; no cesium.

$\mathbf{K a t}_{\mathbf{2}} \mathbf{M o}_{6} \mathbf{I}_{14}$ : The same method as previously described was used with $\mathrm{Cs}_{2} \mathrm{Mo}_{6} \mathrm{I}_{14}(0.052 \mathrm{~g}, 0.02 \mathrm{mmol})$ and $\mathrm{Kat}-\mathrm{Br}(0.05 \mathrm{~g}, 0.045$ $\mathrm{mmol})$. The product was obtained as a red solid.

${ }^{1} \mathrm{H}-\mathrm{NMR}\left(300 \mathrm{MHz}, \mathrm{CDCl}_{3}\right): 1.34-1.39(72 \mathrm{H}, \mathrm{m}), 1.71-1.83(24 \mathrm{H}, \mathrm{m}), 3.16(6 \mathrm{H}, \mathrm{s}), 3.30(12 \mathrm{H}, \mathrm{m}), 4.00(12 \mathrm{H}, \mathrm{t}, \mathrm{J}=6.6 \mathrm{~Hz}), 6.99(12 \mathrm{H}$ Ar, $\mathrm{d}, \mathrm{J}=8.7 \mathrm{~Hz}), 7.53\left(12 \mathrm{H}_{\mathrm{Ar}}, \mathrm{d}, \mathrm{J}=8.7 \mathrm{~Hz}\right), 7.66\left(24 \mathrm{H}_{\mathrm{Ar}}, \mathrm{q}, \mathrm{J}=8.4 \mathrm{~Hz}\right)$. EA: Found: $\mathrm{C}, 38.05 ; \mathrm{H}, 4.22 ; \mathrm{N}, 2.71 \% \mathrm{C}_{140} \mathrm{H}_{174} \mathrm{~N}_{8} \mathrm{O}_{6} \mathrm{I}_{14} \mathrm{Mo}_{6}$ requires $\mathrm{C}, 38.07 ; \mathrm{H}, 3.97 ; \mathrm{N}, 2.54)$. EDS: Mo: 29.78 ; I: $67.36 \%$; no bromine, no cesium.

$\mathrm{Kat}_{2} \mathrm{Mo}_{6} \mathrm{Br}_{8}^{\mathrm{i}} \mathrm{I}_{6}^{\mathrm{a}}$ : $\mathrm{Cs}_{2} \mathrm{Mo}_{6} \mathrm{Br}_{8}^{\mathrm{i}} \mathrm{Br}_{6}^{\mathrm{a}}$ (440 mg, $0.224 \mathrm{mmol}$ ) and $\mathrm{AgBF}_{4}$ (403 mg, $1.45 \mathrm{mmol}$ ) were introduced into a schlenck tube together with $20 \mathrm{~mL}$ of an acetone/ethanol (1/1) solution. This solution was stirred 15 hours in the dark. After filtration of the AgBr precipitate, an ethanol solution of CsI $(2.24 \mathrm{mmol}, 438 \mathrm{mg}$ in $5 \mathrm{ml}$ ) was added to the filtrate. The mixture was stirred for $24 \mathrm{~h}$ in the dark at $25^{\circ} \mathrm{C}$. After evaporation of solvent to dryness, the solid residue was extracted with $30 \mathrm{ml}$ of dry acetone. After filtration, this acetone solution was further dried to give $\mathrm{Cs}_{2} \mathrm{Mo}_{6} \mathrm{Br}_{8}{ }^{\mathrm{a}}{ }_{6}{ }_{6}$ as a polycrystalline solid. $\mathrm{Kat}-\mathrm{Br}(0.05 \mathrm{~g}, 0.045 \mathrm{mmol})$ was dissolved in hot ethanol and added to a solution of $\mathrm{Cs}_{2} \mathrm{Mo}_{6} \mathrm{Br}^{\mathrm{i}}{ }_{8} \mathrm{l}_{6}^{\mathrm{a}}(0.045 \mathrm{~g}, 0.02 \mathrm{mmol})$ in water and the mixture was heated up for $1 \mathrm{~h}$ at $80{ }^{\circ} \mathrm{C}$. The hybrid precipitated form the reaction solution. The product was washed 3 times with water and 3 times with hot ethanol. The product was obtained as an orange oil.

${ }^{1} \mathrm{H}-\mathrm{NMR}\left(300 \mathrm{MHz}, \mathrm{CDCl}_{3}\right): 1.34-1.39(72 \mathrm{H}, \mathrm{m}), 1.71-1.83(24 \mathrm{H}, \mathrm{m}), 3.10(6 \mathrm{H}, \mathrm{s}), 3.22(12 \mathrm{H}, \mathrm{m}), 4.00(12 \mathrm{H}, \mathrm{t}, \mathrm{J}=6.6 \mathrm{~Hz}), 6.99(12 \mathrm{H}$ Ar, $\mathrm{d}, \mathrm{J}=8.7 \mathrm{~Hz}), 7.53\left(12 \mathrm{H}_{\mathrm{Ar}}, \mathrm{d}, \mathrm{J}=8.7 \mathrm{~Hz}\right), 7.66\left(24 \mathrm{H}_{\mathrm{Ar}}, \mathrm{q}, \mathrm{J}=8.4 \mathrm{~Hz}\right)$. EA: Found: $\mathrm{C}, 42.02 ; \mathrm{H}, 4.11 ; \mathrm{N}, 2.87 \% \mathrm{C}_{140} \mathrm{H}_{174} \mathrm{~N}_{8} \mathrm{O}_{6} \mathrm{Br}_{8} \mathrm{I}_{6} \mathrm{Mo}_{6}$ requires $\mathrm{C}, 41.60 ; \mathrm{H}, 4.34 ; \mathrm{N}, 2.77$. EDS: Mo: 34.17; I: 20.99; $\mathrm{Br}$ : $44.84 \%$; no cesium.

\section{Acknowledgements}

We are grateful to UR1, GIS Bresmat, ANR, Region Bretagne and FEDER for financial support. This work has been done in the frame of the ANR Clustomesogen ANR-13-BS07-0003-01. Authors wish to thank Dr. F. Artzner and C. Meriadec for SAXS measurements and Dr. F. Camerel for DSC access.

\section{Notes and references}

${ }^{a}$ Université de Rennes 1- CNRS UMR 6226“Institut des Sciences Chimiques de Rennes“, Campus de Beaulieu, CS 74205, 35042 Rennes Cedex, France. yann.molard@univ-rennes1.fr

${ }^{b}$ Université Européenne de Bretagne, INSA, FOTON, UMR 6082, F-35708 Rennes, France.

${ }^{c}$ Département d'optique Télécom Bretagne, Brest, France.Address here.

Electronic Supplementary Information (ESI) available: Experimental details for single crystals X-ray data collection (CCDC 1045821), DSC thermograms of pure compounds and mixture with E44, SAXS diffractograms of pure compounds and $\mathrm{Kat}_{2} \mathrm{Mo}_{6} \mathrm{I}_{14}: \mathrm{E}_{44} \mathrm{mixture}(1: 9)$ and luminescence decay profiles.

1. H. Coles and S. Morris, Nature Photonics, 2010, 4, 676-685.

2. K. Binnemans, J. Mater. Chem., 2009, 19, 448-453.

3. K. Binnemans, Chem. Rev., 2009, 109, 4283-4374.

4. D. W. Bruce, D. A. Dunmur, E. Lalinde, P. M. Maitlis and P. Styring, Nature, 1986, 323, 791-792.

5. R. W. Date, E. F. Iglesias, K. E. Rowe, J. M. Elliott and D. W. Bruce, Dalton Trans., 2003, 1914-1931. 
6. B. Donnio, D. Guillon, R. Deschenaux and D. W. Bruce, in Comprehensive Coordination Chemistry II: From Biology to Nanotechnology, eds. J. A. Mc Cleverty, J. J. Meyer, M. Fujita and A. Powell, Elsevier, Oxford, 2003, pp. 357-627.

7. S. V. Eliseeva and J. C. G. Bunzli, Chem. Soc. Rev., 2010, 39, 189-227.

8. A. L. Rodarte, C. Gray, L. S. Hirst and S. Ghosh, Phys. Rev. B, 2012, 85, 035430/035431-035430/035436.

9. C.-T. Chen, C.-C. Liu, C.-H. Wang, C.-W. Chen and Y.-F. Chen, Appl. Phys. Lett., 2011, 98, 261918/261911-261918/261913.

10. K. Yuan, F. Li, L. Chen, Y. Li and Y. Chen, J. Phys. Chem. C, 2012, 116, 6332-6339.

11. F. Li, Q. Li and Y. Chen, J. Lumin., 2012, 132, 2114-2121.

12. S. Saliba, Y. Coppel, P. Davidson, C. Mingotaud, B. Chaudret, M. L. Kahn and J.-D. Marty, J. Mater. Chem., 2011, 21, $6821-6823$.

13. L. J. Martinez-Miranda, K. M. Traister, I. Melendez-Rodriguez and L. Salamanca-Riba, Appl. Phys. Lett., 2010, 97, 223301/223301-223301/223303.

14. C. Neaime, M. Prévôt, M. Amela-Cortes, V. Cîrcu, F. Grasset, H. Folliot and Y. Molard, Chem. Eur. J., 2014, 20, $17770-13776$.

15. M. F. Prodanov, N. V. Pogorelova, A. P. Kryshtal, A. S. Klymchenko, Y. Mely, V. P. Semynozhenko, A. I. Krivoshey, Y. A. Reznikov, S. N. Yarmolenko, J. W. Goodby and V. V. Vashchenko, Langmuir, 2013, 29, 9301-9309.

16. Y. Molard, F. Dorson, V. Circu, T. Roisnel, F. Artzner and S. Cordier, Angew. Chem. Int. Ed. Engl., 2010, 49, $3351-3355$.

17. A. S. Mocanu, M. Amela-Cortes, Y. Molard, V. Circu and S. Cordier, Chem. Commun., 2011, 47, 2056-2058.

18. Y. Molard, A. Ledneva, M. Amela-Cortes, V. Circu, N. G. Naumov, C. Meriadec, F. Artzner and S. Cordier, Chem. Mater., 2011, 23, 5122-5130.

19. M. Amela-Cortes, F. Dorson, M. Prévôt, A. Ghoufi, B. Fontaine, F. Goujon, R. Gautier, V. Cîrcu, C. Mériadec, F. Artzner, H. Folliot, S. Cordier and Y. Molard, Chem. Eur. J., 2014, 20, 8561-8565.

20. M. Amela-Cortes, S. Cordier, N. G. Naumov, C. Meriadec, F. Artzner and Y. Molard, J. Mater. Chem. C., 2014, 2, $9813-9823$.

21. S. K. Nayak, M. Amela-Cortes, C. Roiland, S. Cordier and Y. Molard, Chem. Commun., 2015, DOI: 10.1039/C1034CC10085A.

22. T. G. Gray, C. M. Rudzinski, D. G. Nocera and R. H. Holm, Inorg. Chem., 1999, 38, 5932-5933.

23. T. G. Gray, C. M. Rudzinski, E. E. Meyer, R. H. Holm and D. G. Nocera, J. Am. Chem. Soc., 2003, 125, 4755-4770.

24. F. A. Cotton, Inorg. Chem., 1964, 3, 1217-1220.

25. A. W. Maverick, J. S. Najdzionek, D. MacKenzie, D. G. Nocera and H. B. Gray, J. Am. Chem. Soc., 1983, 105, $1878-1882$.

26. M. N. Sokolov, M. A. Mihailov, E. V. Peresypkina, K. A. Brylev, N. Kitamura and V. P. Fedin, Dalton Trans., $2011,40,6375-6377$.

27. Y. Zhao and R. R. Lunt, Adv. Energy Mater., 2013, 3, 1143-1148.

28. A. W. Maverick and H. B. Gray, J. Am. Chem. Soc., 1981, 103, 1298-1300.

29. J. R. Long, A. S. Williamson and R. H. Holm, Angew. Chem. Int. Ed. Engl., 1995, 34, 226-229.

30. S. Cordier, K. Kirakci, D. Mery, C. Perrin and D. Astruc, Inorg. Chim. Acta, 2006, 359, 1705-1709.

31. S. Ababou-Girard, S. Cordier, B. Fabre, Y. Molard and C. Perrin, ChemPhysChem, 2007, 8, 2086-2090.

32. F. Grasset, F. Dorson, S. Cordier, Y. Molard, C. Perrin, A.-M. Marie, T. Sasaki, H. Haneda, Y. Bando and M. Mortier, Adv. Mater., 2008, 20, 143148.

33. F. Grasset, F. Dorson, Y. Molard, S. Cordier, V. Demange, C. Perrin, V. Marchi-Artzner and H. Haneda, Chem. Commun., 2008, 4729-4731.

34. F. Grasset, Y. Molard, S. Cordier, F. Dorson, M. Mortier, C. Perrin, M. Guilloux-Viry, T. Sasaki and H. Haneda, Adv. Mater., $2008,20,1710-1715$.

35. B. Fabre, S. Cordier, Y. Molard, C. Perrin, S. Ababou-Girard and C. Godet, J. Phys. Chem. C, 2009, 113, 17437-17446.

36. T. Aubert, F. Grasset, S. Mornet, E. Duguet, O. Cador, S. Cordier, Y. Molard, V. Demange, M. Mortier and H. Haneda, J. Colloid Interface Sci., 2010, 341, 201-208.

37. T. Aubert, A. Y. Ledneva, F. Grasset, K. Kimoto, N. G. Naumov, Y. Molard, N. Saito, H. Haneda and S. Cordier, Langmuir, $2010,26,18512-18518$. 38. J. R. Long, L. S. McCarty and R. H. Holm, J. Am. Chem. Soc., 1996, 118, 4603-4616.

39. H. D. Selby, B. K. Roland and Z. Zheng, Acc. Chem. Res., 2003, 36, 933-944.

40. D. Mery, L. Plault, S. Nlate, D. Astruc, S. Cordier, K. Kirakci and C. Perrin, Z. Anorg. Allg. Chem., 2005, 631, $2746-2750$.

41. D. Mery, L. Plault, C. Ornelas, J. Ruiz, S. Nlate, D. Astruc, J. C. Blais, J. Rodrigues, S. Cordier, K. Kirakci and C. Perrin, Inorg. Chem., 2006, 45, 1156-1167.

42. L. F. Szczepura, K. A. Ketcham, B. A. Ooro, J. A. Edwards, J. N. Templeton, D. L. Cedeno and A. J. Jircitano, Inorg. Chem., $2008,47,7271-7278$.

43. G. Prabusankar, Y. Molard, S. Cordier, S. Golhen, Y. Le Gal, C. Perrin, L. Ouahab, S. Kahlal and J. F. Halet, Eur. J. Inorg. Chem., 2009, 21532161.

44. Y. Molard, F. Dorson, K. A. Brylev, M. A. Shestopalov, Y. Le Gal, S. Cordier, Y. V. Mironov, N. Kitamura and C. Perrin, Chem. Eur. J., 2010, 16, 5613-5619.

45. S. Cordier, F. Grasset, Y. Molard, M. Amela-Cortes, R. Boukherroub, S. Ravaine, M. Mortier, N. Ohashi, N. Saito and H. Haneda, J. Inorg. Organomet. Polym. Mater., 2014, 1-16.

46. C. F. J. Faul and M. Antonietti, Adv. Mater., 2003, 15, 673-683.

47. K. Binnemans, Chem. Rev., 2005, 105, 4148-4204.

48. C. F. J. Faul, Mol. Cryst. Liquid Cryst., 2006, 450, 255-265.

49. J. C. Sheldon, J. Chem. Soc., 1960, 1007-1014.

50. J. C. Sheldon, J. Chem. Soc., 1962, 410-415.

51. M. Potel, C. Perrin, A. Perrin and M. Sergent, Mater. Res. Bull., 1986, 21, 1239-1245.

52. W. Preetz, D. Bublitz, H. G. Vonschnering and J. Sassmannshausen, Z. Anorg. Allg. Chem., 1994, 620, $234-246$. 
53. P. Bruckner, W. Preetz and M. Punjer, Z. Anorg. Allg. Chem., 1997, 623, 8-17.

54. K. Kirakci, S. Cordier and C. Perrin, Z. Anorg. Allg. Chem., 2005, 631, 411-416.

55. M. D. Everaars, A. T. M. Marcelis and E. J. R. Sudholter, Colloid Surf. A-Physicochem. Eng. Asp., 1995, 102, 117-126.

56. M. D. Everaars, A. T. M. Marcelis and E. J. R. Sudholter, Langmuir, 1993, 9, 1986-1989.

57. E. Terazzi, G. Rogez, J.-L. Gallani and B. Donnio, J. Am. Chem. Soc., 2013, 135, 2708-2722.

58. C. Tschierske and Editor, Liquid Crystals: Materials Design and Self-Assembly. [In: Top. Curr. Chem., 2012; 318 ], 2012.

59. E. Terazzi, C. Bourgogne, R. Welter, J.-L. Gallani, D. Guillon, G. Rogez and B. Donnio, Angew. Chem., Int. Ed., 2008, 47, 490-495.

60. I. M. Saez and J. W. Goodby, Struct. Bond., 2008, 128, 1-62.

61. J. W. Goodby, I. M. Saez, S. J. Cowling, V. Gortz, M. Draper, A. W. Hall, S. Sia, G. Cosquer, S. E. Lee and E. P. Raynes, Angew. Chem. Int. Edit. Engl., 2008, 47, 2754-2787.

62. B. Li, J. Zhang, S. Wang, W. Li and L. Wu, Eur. J. Inorg. Chem., 2013, 2013, 1869-1875.

63. W. Li, S. Y. Yi, Y. Q. Wu and L. X. Wu, J. Phys. Chem. B, 2006, 110, 16961-16966.

64. W. Li, S. Y. Yin, J. F. Wang and L. X. Wu, Chem. Mater., 2008, 20, 514-522.

65. I. M. Saez and J. W. Goodby, J. Mater. Chem., 2005, 15, 26-40.

66. K. Kirakci, P. Kubat, J. Langmaier, T. Polivka, M. Fuciman, K. Fejfarova and K. Lang, Dalton Trans., 2013, 42, $7224-7232$.

67. K. Kirakci, K. Fejfarova, M. Kucerakova and K. Lang, Eur. J. Inorg. Chem., 2014, 2014, 2331-2336.

68. K. Kirakci, P. Kubat, M. Dusek, K. Fejfarova, V. Sicha, J. Mosinger and K. Lang, Eur. J. Inorg. Chem., 2012, $3107-3111$.

69. R. Ramirez-Tagle and R. Arratia-Perez, Chem. Phys. Lett., 2008, 460, 438-441.

70. M. Draper, I. M. Saez, S. J. Cowling, P. Gai, B. Heinrich, B. Donnio, D. Guillon and J. W. Goodby, Adv. Funct. Mater., $2011,21,1260-1278$.

71. S. T. Wu, E. Ramos and U. Finkenzeller, J. Appl. Phys., 1990, 68, 78-85.

72. M. Roessle, E. Manakova, I. Lauer, T. Nawroth, J. Holzinger, T. Narayanan, S. Bernstorff, H. Amenitsch and H. Heuman, J. Appl. Cryst., 2000, 33, 548-551. 